\title{
The Analysis of the Turkish Islamic Banking System between 2005 and 2014
}

\author{
Lívia Tálos (Kaposvár University, Hungary) \\ Dr. Gyöngyi Bánkuti (Kaposvár University, Hungary) \\ Dr. Jozsef Varga (Kaposvar University, Hungary)
}

\begin{abstract}
Islamic banking is a banking system that is based on the principles of sharia or Islamic law. The principles of Islamic finance forbid interest - this is commonly known as riba - charity (zakat), forbid high risk (gharar), forbid some transactions like gambling, and are based on PLS (Profit-Loss Share). The most important concept is that both charging and receiving interest are strictly forbidden; money may not generate profits. Islamic banks have largely survived the global economic crisis intact and they offer a safer operation than conventional banks. CAMEL analysis is a supervisory rating system to classify a bank's overall condition according to Capital (C), Assets (A), Management (M), Earnings (E) and Liquidity (L). In the analysis a variety of indicators were calculated based on data from the annual reports. The results of the four banks were averaged separately, then classified $(1=\operatorname{good}, 2$ = adequate, 3 = satisfactory, $4=$ acceptable, $5=$ unacceptable) according to the desired criteria, the changes over the years and the relative values of the four banks.
\end{abstract}

\section{Introduction}

Since the outbreak of the 2008 economic crisis the issue of the stability of the banking system has become increasingly important. The attention has turned from traditional financing strategies to alternative financing forms, and the banks operating on Islamic religious principles have been given a greater role, since they were hit less harder by the crisis than conventional banks (Varga, 2011).

Financial stability is a condition in which the financial system, including key financial markets and financial institutions, is resistant to economic shocks and able to fulfil seamlessly its key functions: intermediating financial resources, management of risk and payment transactions. '(www.mnb.hu, 2015).

In most countries the 2008 economic crisis appeared as a banking crisis, which was reflected by bank failures, recapitalization and nationalization. According to the IMF, bank crisis means phenomena which manifest themselves in the number of increased bankruptcies, in the increase in the proportion of non-performing loans and in the reduction of the banking system's capital, and these processes are associated with the drastic fall in stock and real estate prices, with the rise in real interest rates and with the slowdown of capital inflows (Flecser, et al, 2010). Financial institutions have widely used the deliberate and massive leverage. The main downside of this is that the whole financial system might be threatened if the losses occurring in the case of assets increase counterparty risk and undermine trust. When this actually occurred, the illiquid assets write-offs enforced in developed countries have increased solvency risk and as a counterbalancing attempt a rapid leverage dismantling took place (Nagy, 2010).

The operation of the Islamic banks is based on religious principles; therefore, it can be difficult to understand for the Western world. The primary and fundamental source of Islam is the Islamic holy book, the Quran. The Quran summarizes the early foundations of the faith, the history of mankind, the relationship between God and man, and the conditions of bringing people together (Prieger-Mátyás, 2014). According to Islam, the money is just a simple instrument and it has no value by itself, it is merely used to measure the value of things. On the basis of this it is prohibited to produce money from money by funds rate (Balázs, 2011). "And whatever you give for interest to increase within the wealth of people will not increase with Allah. But what you give in zakah, desiring the countenance of Allah - those are the multipliers." (Quran 30:39).

The operation of the Islamic financial transactions and banking products is rooted in the Islamic religion within that in the Islamic law or saria; that is one must comply with the Sharia requirements in carrying out such operations (Pálfi, 2010).Five principles should be applied; i.e. Sharia extends five main rules for economic activities. The first and perhaps most well-known principle is the prohibition of charging interest or riba (usury). Charging interest was illegal according to Islamic law and was rejected; i.e. it was not allowed to ask for interest on money loans (Balazs, 2011). The second principle is that Zakąt should appear in financing transaction, i.e. the charity of our giving. The next principle is that financial transactions opposing the Islamic values are prohibited. Such transactions are alcohol, gambling or the financing of warfare trade. Unreasonable risk-taking during a financial transaction is also prohibited. In addition to the prohibition of charging interest, or riba, the gharar; i.e. too risky transactions and majszir, i.e. gambling are all prohibited activities for Islamic financial life. The fifth principle is PLS, that is the profit and loss sharing. A transaction may only be undertaken if the risks are shared among the participants (Pálfi, 2010). 
Only those transactions can be undertaken which are compatible with the principles of Islam and where participants have a share from the achieved profit and bear the losses in proportion of their contribution (Balázs, 2011). An Islamic bank can be successful through adherence to the five principles. The phrase 'halal' is used if the transactions comply with the law. In the event of conflict with the principle the phrase haram is used (Pálfi, 2010).

The study aims to examine the behaviour of the Turkish Islamic banks operating according to religious principles, in the period between 2005 and 2014. We search to answer the question what makes Islamic banks different from conventional banks and we present the performance of Turkish Islamic banks with the help of financial indicators, mainly the changes occurring in their operations due to the crisis. In the analysis the CAMEL method was used, which examines the banks according to 5 factors: Capital adequacy, Asset quality, Management, Earnings and Liquidity.

\section{The Turkish Banking System and the Period of the Crisis}

The 2008 crisis initially seemed to have no significant effect on the Turkish economy. Following the conclusion of their IMF program they were proud to report that they would not need the IMF's help in the future. The banking system was healthy, which meant that the capital adequacy ratio was adequate, and there have been only few bad credits. Then the momentum was broken, which was attributed to domestic political reasons and to a halt in the EU accession. Turkey's banking system can be divided into three distinct parts. The first one is Depository Banks, the second is Development and Investory Banks and finally the Islamic banks or interest-free banks. The Turkish banking system consists of 49 banks; four of them operate according to Islamic banking principles (TKBB Annual Report, 2013).

Albaraka Turk Participation Bank Inc. was founded in 1985. The bank is $66 \%$ owned by foreign investors, $54 \%$ by the Albaraka Banking Group, and $7.84 \%$ by the Islamic Development Bank, the rest being owned by other investors. Asya Participation Bank Inc. is the youngest, as it was founded on 24th of October in 1996. Kuveyt Turk Participation Bank Inc., founded in 1989, deals with interest-free financing and is also owned by the Islamic Development Bank (9\%).and the Kuwait Finance House (62\%). Turkiye Finance Participation Bank Inc. was formed on 3rd of October in 1991 (TKBB Annual Report, 2013). Here we would like to mention that the fifth Islamic bank the Turkish Ziraat Participation Bank was founded on 14th of October in 2015 (www.ziraatkatilim.com.tr).

The most significant part of the financial market is the banking sector, followed by the insurance industry and then the public funds. The crisis has slowed down the pace of opening new bank branches and troubles have occurred in the area of lending and credit card business. The number of non-performing credit card debts reached 2.5 million. Despite all these, the Turkish banking sector was able to maintain growth and profitability. The Turkish banks were disciplined and operated under strict rules during the crisis. Learning from the previous recession (2000-2001).they pursued a credit policy with which they could remain profitable. However, it should be noted that the provision for non-performing loans is a serious impediment to growth (TKBB Annual Report, 2013).

Overall, the global economic crisis in late 2008 and in the first quarter of 2009 appeared significantly in the Turkish economy's performance, but as far as the banking sector is concerned, the banking sector's profitability has improved rapidly as a result of the reduction of the base rate by the Central Bank. The Turkish real economy was influenced significantly by the international fluctuations, but if we compare it with the money market, it turns out that Turkey has not conducted such an intensive exchange policy as other countries, and none of the banks or financial institutions went bankrupt or had other major difficulties (TKBB Annual Report, 2009).

After the outbreak of the crisis the interest-free banks got into the centre of attention which operates according to Islamic principles. These banks did not have such "toxic" assets as traditional banks, their loans were not converted into securities, and did not undertake high-risk commercial transactions, nor did they speculate. As soon as the attention was focused on interest-free banking, or, as the world calls it, Islamic banks, several conventional banks have started to open such departments (TKBB Annual Report, 2009). These sections are called 'Islamic windows'. Following the 2008 crisis the demand for Islamic financial products increased, and conventional banks took advantage of this trend and started to open Islamic departments. These windows operate completely according to Islamic principles (Gálosi, 2010).

\section{Material and Method}

In the primary research the analysis was done on the basis of data from the Turkish Islamic banks' reports between 2005 and 2014. The Turkish Islamic banks prepare their annual report according to International Financial Reporting Standards (IFRS) so that they become internationally comparable. The data for the analysis come from the unconsolidated financial statements. During the examination, the CAMEL method was used which gives us comprehensive view about Capital adequacy, Asset quality, the Management, Profitability, and about Liquidity. The CAMEL method is a subjective grading method, but in this case we use it with the objective of presenting the evolution of the performance of the banks. 
The selection of the best indicators of banking activities can be difficult. The CAMEL analysis is considered to be the most appropriate method. The CAMEL method was introduced in 1979 by the US banking supervisors. The mosaic word consists of the following five components:

C - Capital Adequacy

A - Asset

M - Management

E - Earnings

L - Liquidity.

On the basis of this method the analysis of the banks is done in two steps. In the first step the individual factors are graded on a scale of 5 points:

$1=\operatorname{good}$

$2=$ sufficient

$3=$ satisfactory

$4=$ acceptable

$5=$ inadequate.

The next step is the overall classification of financial institutions also on a 5-point scale as an average of the previous ratings:

$1=$ financially strong

2 = basically good, few problems

$3=$ major problems exist

$4=$ deteriorated financial situation

$5=$ high probability of bankruptcy (Baka, et. al, 2012)

\section{The CAMEL Analysis}

In the analysis a variety of indicators were calculated based on data from the annual reports. For the test we used data from the Islamic banks' annual reports in English and in Turkish language between 2005 and 2014, which are available for downloading from their websites on the Internet. On the basis of five criteria 2 indicators per criterion were calculated and evaluated. The results of the four banks were averaged separately, then classified $(1=$ good, 2 = adequate, 3 = satisfactory, $4=$ acceptable, $5=$ unacceptable) according to the desired criteria, the changes over the years and the relative values of the four banks.

\subsection{Capital Adequacy}

The main task of the Capital adequacy ratio (CAR) is maintaining the bank's long-term solvency. The indicator expressing solvency is used worldwide; the value of this index should be at least $8 \%$ in accordance with the Basel standards. Changes in Capital adequacy ratios are shown in the figure below; the data come from the banks' annual reports.

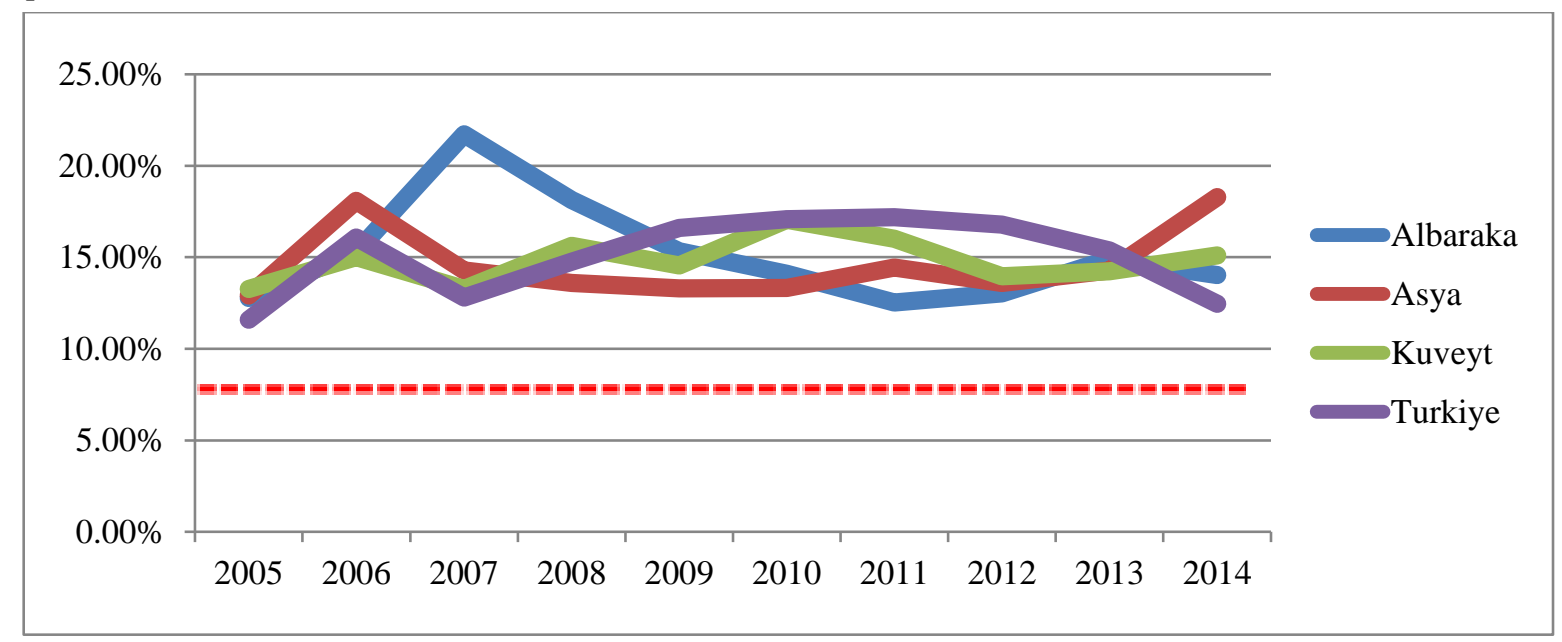

Figure 1. Trends in the Capital Adequacy Ratios

We can see that in the examined years all banks met the $8 \%$ criteria (----) moreover, they reached even higher than that.

In 2007, Albaraka Bank's capital adequacy ratio was above $20 \%$, and then decreased until 2011. During the period of the crisis, the Turkish Islamic banks' indicators fell slightly due to the increase in troubled assets, but after that they could keep their solvency.

The banks are classified as 1 . 
The Leverage ratio values are shown in the following figure. The results of the indicator were obtained by comparing own capital to the relative values of the balance sheet total.

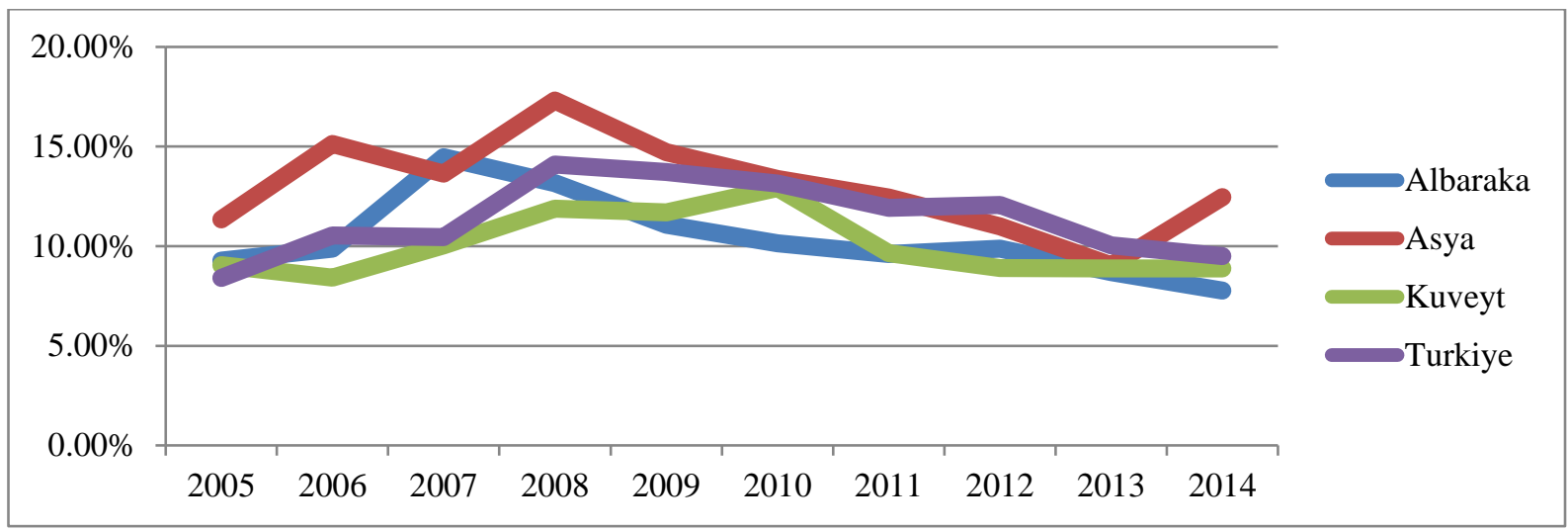

Figure 2. Changes in the Leverage Ratios

The indicator also provides information about the bank's prudence, namely the distribution of equity and debt. The indicator can be interpreted that in 2007 Albaraka Bank's equity accounted for $14.47 \%$ of foreign funds, then the index fell. In the case of Asya it was $13.63 \%$, in the case of Kuveyt it was $10.04 \%$, and $10.46 \%$ in the case of Turkiye. The reductions of the indicators suggest that the equity ratio increased. Banks mostly manage foreign resources so a high leverage is typical.

If the ratio of foreign funds were too high, it would mean that the Turkish Islamic banks pursue risky activities. In this case, following the crisis the change was a decline, i.e. we can talk about careful business, which, however, in turn could lead to a deterioration of profitability. Four of the banks are classified as 3 .

The Turkish Islamic banking sector's capital adequacy is stable, its Capital adequacy indicators were in line with the accepted value and its solvency was not threatened.

\subsection{Assets}

Lending activities are especially important for banks, so it is essential to analyse the quality of the assets in terms of the bank's successful operation and efficiency. We mainly analyse classified loans, especially Non-performing loans (NPL) compared to total loans; i.e. what the proportion of the credit loss is in the total loans. In the crisis a significant jump in the non-performing loans was typical.

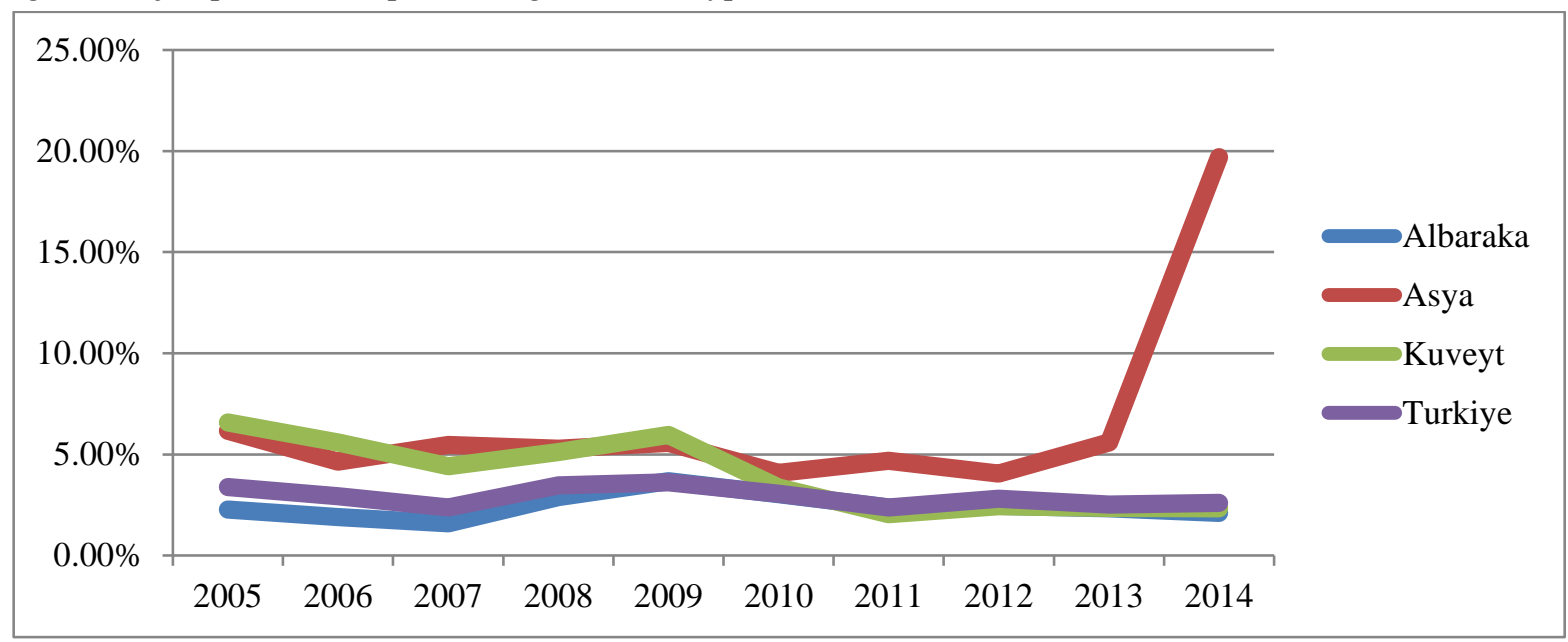

Figure 3. NPL Ratios to Total Loan Portfolios

The figure provides information about the level of Non-performing loans in the total loan portfolio. However, the value of Non-performing loans below $5 \%$ is acceptable.

We can see that between 2008-2009, during the crisis there was a slight increase in the proportion of Nonperforming loans for all four banks and the values of Kuveyt and Asya jumped above the accepted value. However, still nearly $95 \%$ of the loans have no problems. From 2010 to 2012, there may have been adverse events in the operation of Bank Asya, as the proportion of Non-performing loans increased significantly. In 2014, the proportion of the non performing loans to total loan portfolio was $19.70 \%$, which could be attributed to the negative conditions in the consumer loans and credit card business sector. 
To sum up, in the case of banks' operation we can talk about prudential operation, because the credits account only for a very small proportion of the total loan losses, and the other banks' indicators move together from 2011 except Asya. Bank Asya is classified as 4 due to the increase and the average values above 5\%.

The proportion of loans to total assets is shown in the following figure.

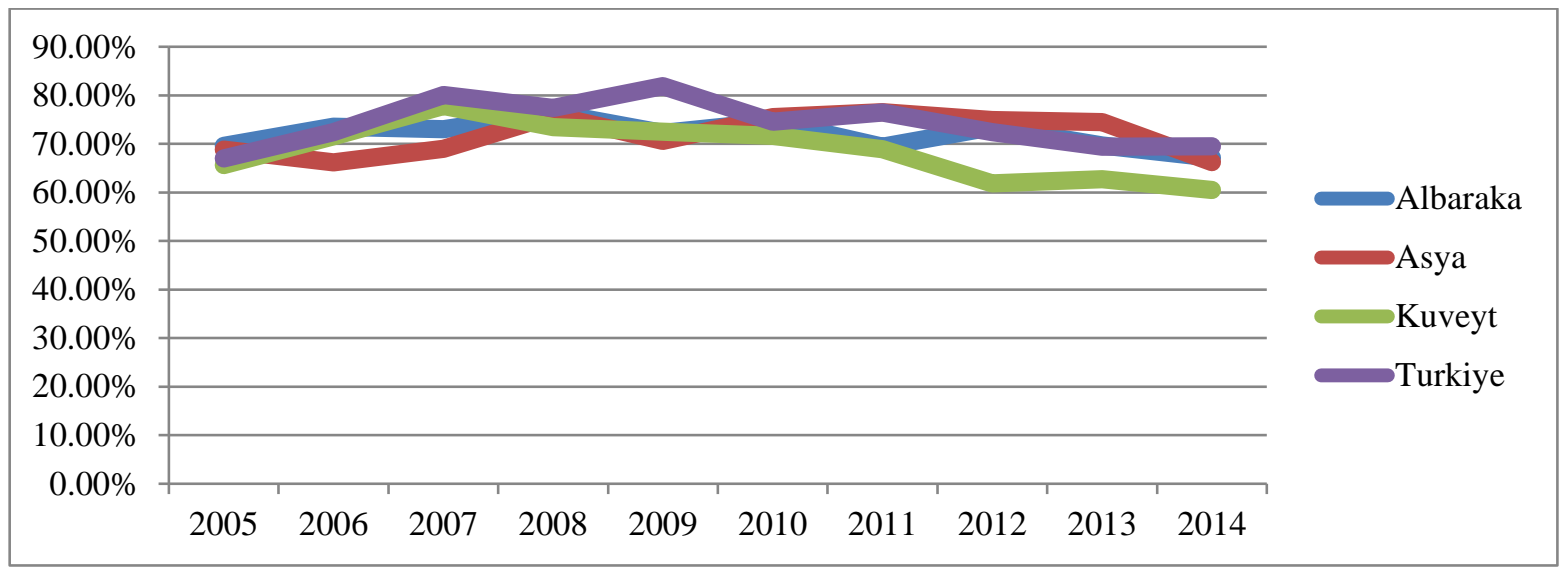

Figure 4. Changes of the Loan Portfolios

It can be seen that the banks' activity is dominated by lending with more than $70 \%$. On the positive side, all of the banks' loan portfolio was higher year after year; i.e. their lending activity has not slowed down. However, we can approach this also from the perspective that a high loan portfolio can be risky, so considering safety i.e. because of the risk of return a high loan portfolio can be negative. However, in the case of banks, lending means a greater profitability than investments for example. The banks are classified as 1 .

\subsection{Management}

The bank's management is extremely important because the strength and the effectiveness of banks may depend on the type of the leadership and its ability to recognize risks and restore operations growth path. This factor is mainly examined with cost efficiency indicators.

The revenues of the Turkish Islamic banks were obtained from Income Statements of Annual reports. Total revenue consists of the revenue from Fees and commissions, Income from trading and other revenues. Naturally, interest and similar income are not found in Islamic banks' revenues. The most significant items are Revenues. This item was unfavourable in 2010, compared to 2009 it decreased by $4.02 \%$ for the whole banking system. Revenues consist of Profit from loans, Profits from the thovable assets,"from the Sale and from Leasing of financial income.

The total cost of the Turkish Islamic banks consists of Expenditures and Other spending items, in which a steady increase was registered during the reference years.

The Cost / Revenue ratio is shown in the following figure.

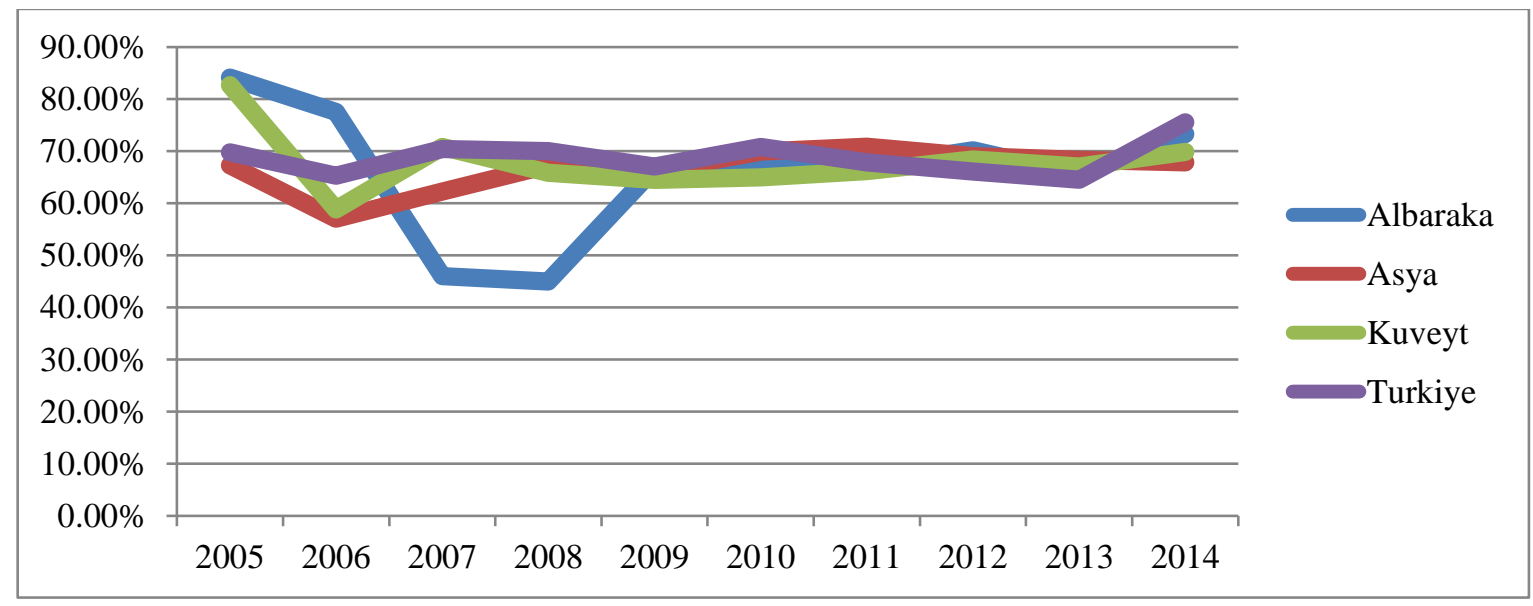

Figure 5. Ratio of Cost/Revenue

The higher the index is the less efficiently a bank operates, i.e. costs erode larger and larger parts of the revenue. The improvement in the cost-effectiveness can be discovered in some places, but it is not significant. Costs consume more than $60 \%$ of the revenue. Comparing the four banks, Turkiye proved to be the least cost-effective, 
and we can see that the ratio of the fourth bank move together from 2009. The banks are classified as 4 due to the high costs.

The following efficiency indicator is Revenue proportionate earnings.

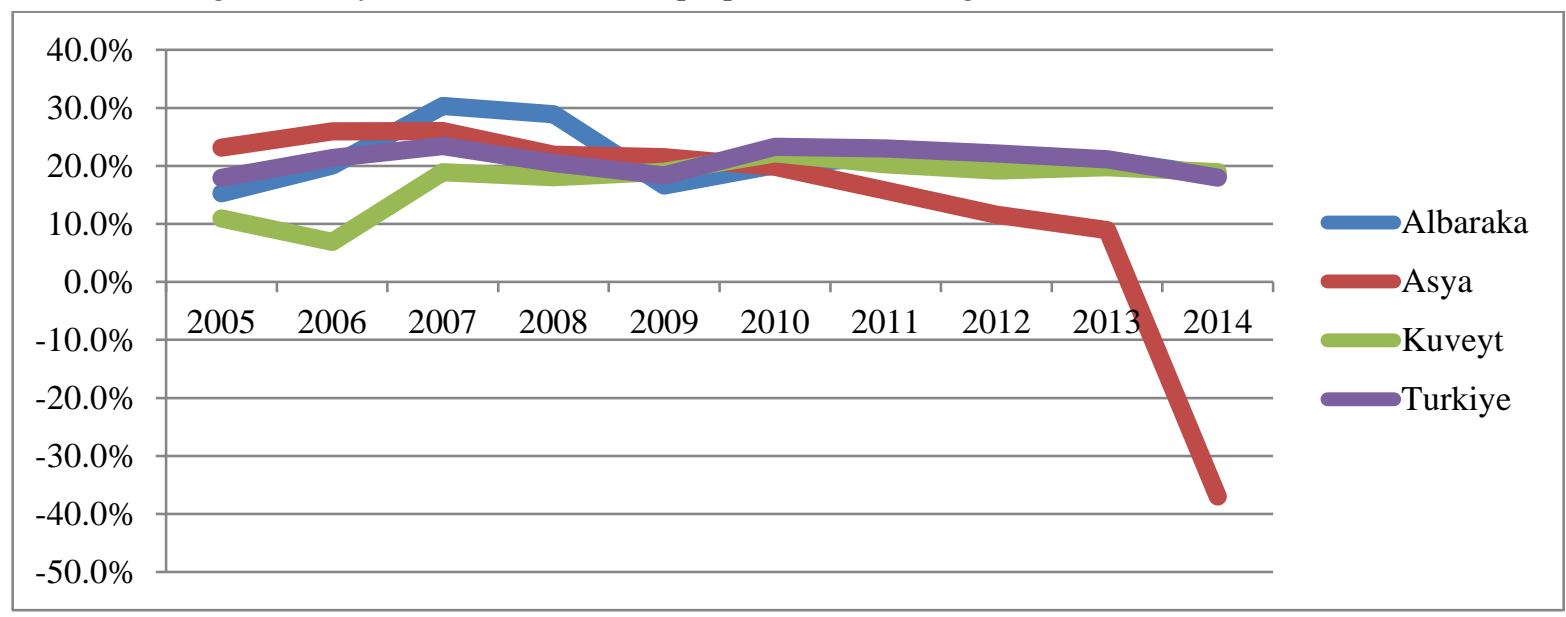

Figure 6. Trends in Revenue Proportionate Earnings

The pre-tax profit/total revenue ratio reflects the operational efficiency, namely how much of the proceeds is made up by the profits. It is clear that the index value fell between 2008 and 2009, but since 2009 the Turkish banks have been improving except Asya. In the case of Bank Asya the negative tendency can be attributed to the loss in 2014. Albaraka, Kuveyt and Turkiye banks are classified as 2, Asya is classified as 3.

The efficiency of the banks showed a slight declining performance due to adverse changes in the costs, which have risen at the expense of profits. Overall, the examination of the Turkish Islamic banking performance indicators showed no dramatic changes except in Asya, which has been in the red since 2013.

\subsection{Earnings}

By using the profitability indicators we can gain information about the effectiveness of management, i.e. how effectively the available funds and the assets acquired from them are used to generate profits. The Turkish banks managed effectively, as net profits grew. But if we analyse the banks one by one there was a decline in 2009 in the case of Albaraka and in the case of Asya from 2010.

As we mentioned, we cannot find interest and similar income in the Islamic banks' profit, but nonetheless they are managed effectively. Return on equity (ROE) and Return on assets (ROA) are commonly used indicators of profitability.

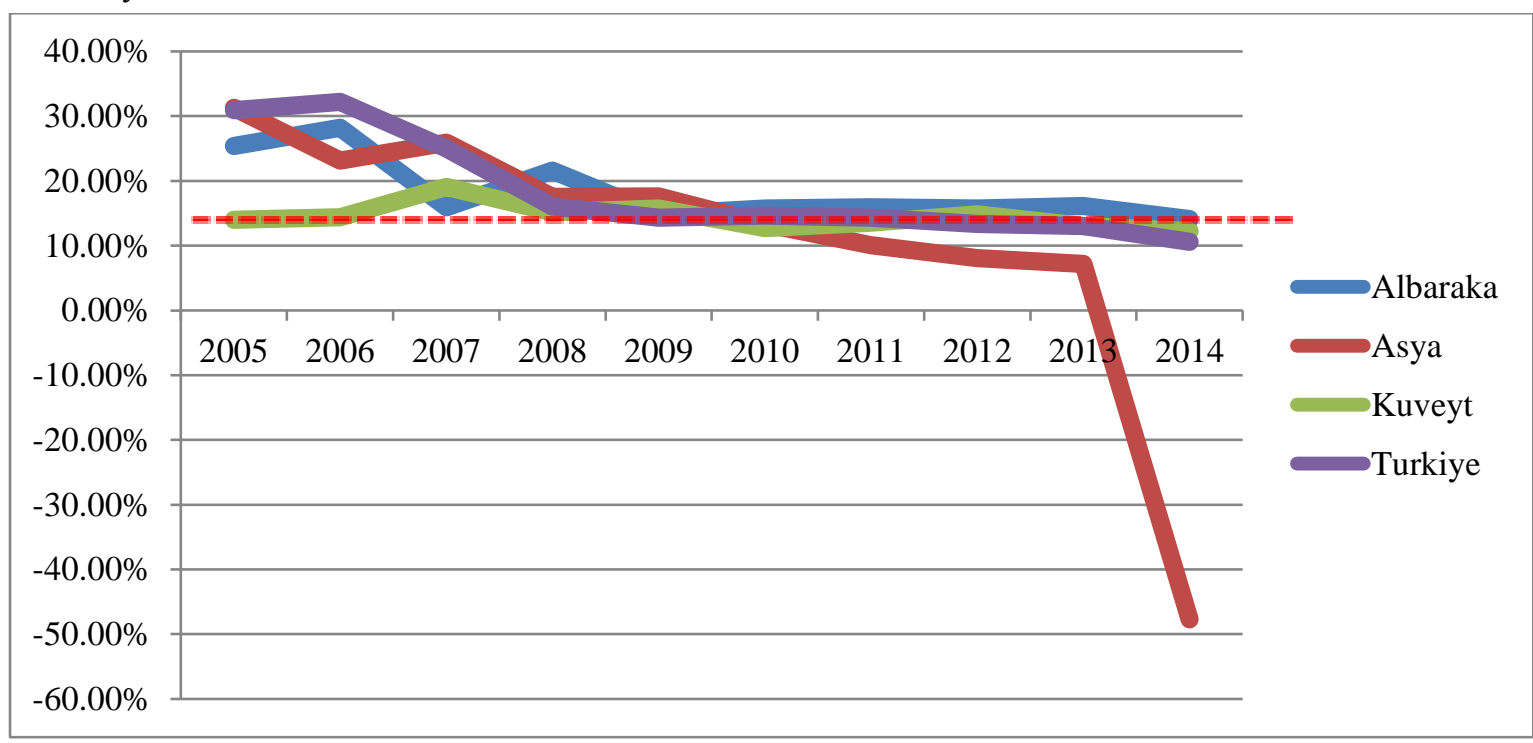

Figure 7. Changes of the ROE Indicators

ROE reflects how the equity produces profit. In case of banks a healthy ROE is around 10-12\% (----). In the case of Bank Asya the indicator is sometimes negative. The profitability decreased significantly and steadily from 2009, which can be explained with the decrease of the net result, and since 2013 it has had negative profit after tax. This resulted in negative ROE and ROA indicators. A negative result can be explained by the fact that due to 
the high rate of non-performing loans provision had to be made, which worsened the outcome. If the ROE is too low, it can also pose risks, since in this case there is a danger that the growth will be marred by another source involved in the operation.

Asya is classified as 3 due to the negative tendency; the other banks are classified as 1 .

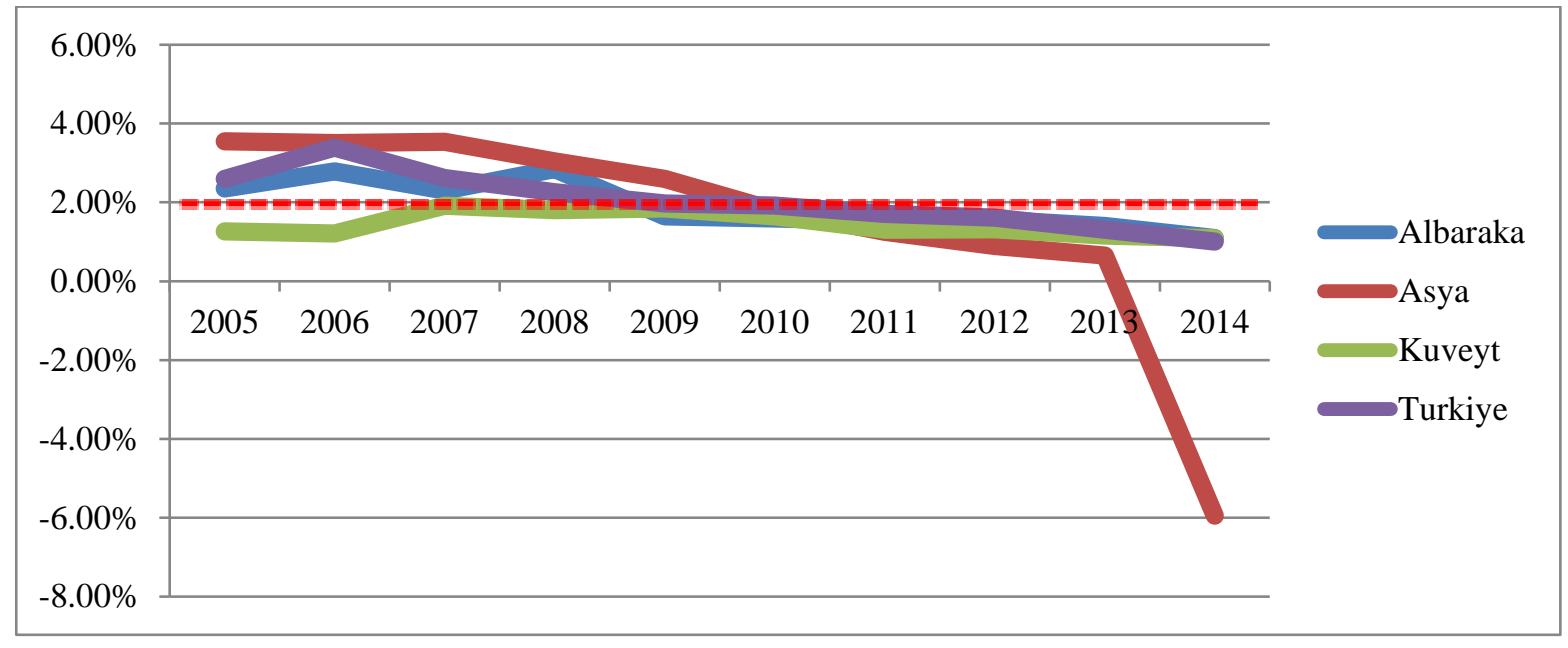

Figure 8. Changes of the ROA Indicators

The ROA gives us data about banks' assets. It shows how good and effective the banks' placements are. The value of the index between 1 and 2 (----) is estimated to be good. The decline of the indexes reflects the deterioration in the banks' recovery. From 2009 a downward trend can be observed. The downward trend in ROA is typical, but it is still within the limits.

In the case of Bank Asya we can see a gradual decline, and in 2014 Bank Asya closed with negative results. Earlier we saw that the Turkish banks' leverage ratio was in decline, which is likely to have a negative effect on the profitability and pushed it down. Asya is classified as 3, the other banks are classified as 1 .

\subsection{Liquidity}

The liquidity indicator informs you how fast the banks' financial instruments can be converted to cash without losses. The higher the index value is the more liquid a bank can be considered. Of course, liquid assets mean lower returns than illiquid assets, so it is important to choose the right assets. The liquid assets of Islamic banks include I. Cash and deposit accounts in the Central Bank, III. Interbank deposits, as well as the V. Financial assets for sale. Item I. Cash and deposit accounts at the Central Bank are clearly the bulk of the Turkish banks' liquid assets.

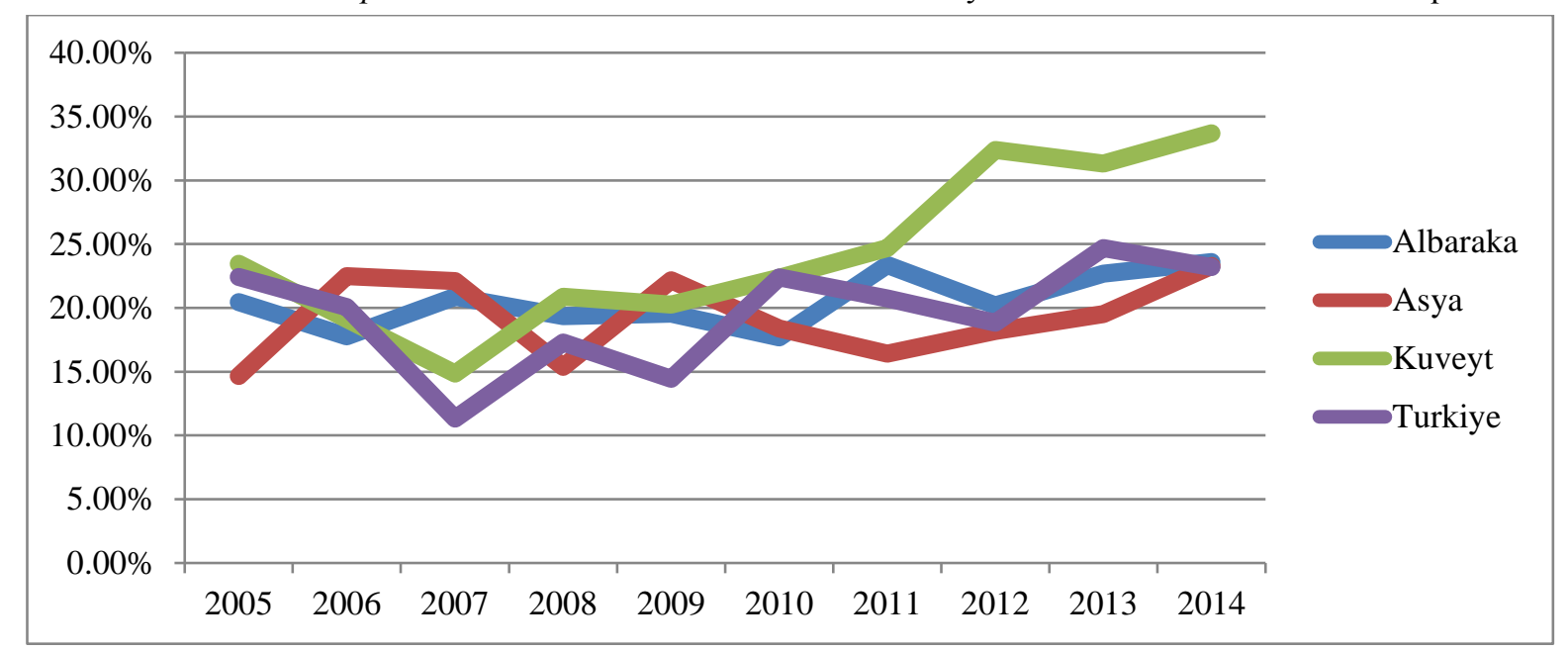

Figure 9. Changes of the Liquidity Ratios

We get a fluctuating picture of the changes of the liquidity of individual banks. The increase and decrease in liquidity may be explained by the changes of banks' liquid assets. In the case of Islamic banks the increase in liquidity can be explained by the rise in Cash and Central Bank accounts. Overall, we can say that the Turkish banks have sufficient liquidity. The banks are classified as 1 .

The Banks' business policy is indicated by the Loan/Deposit ratio. The value of the index above $100 \%$, that is, when the ratio of the loans exceeds the ratio of the deposits, it means aggressive business policy. 


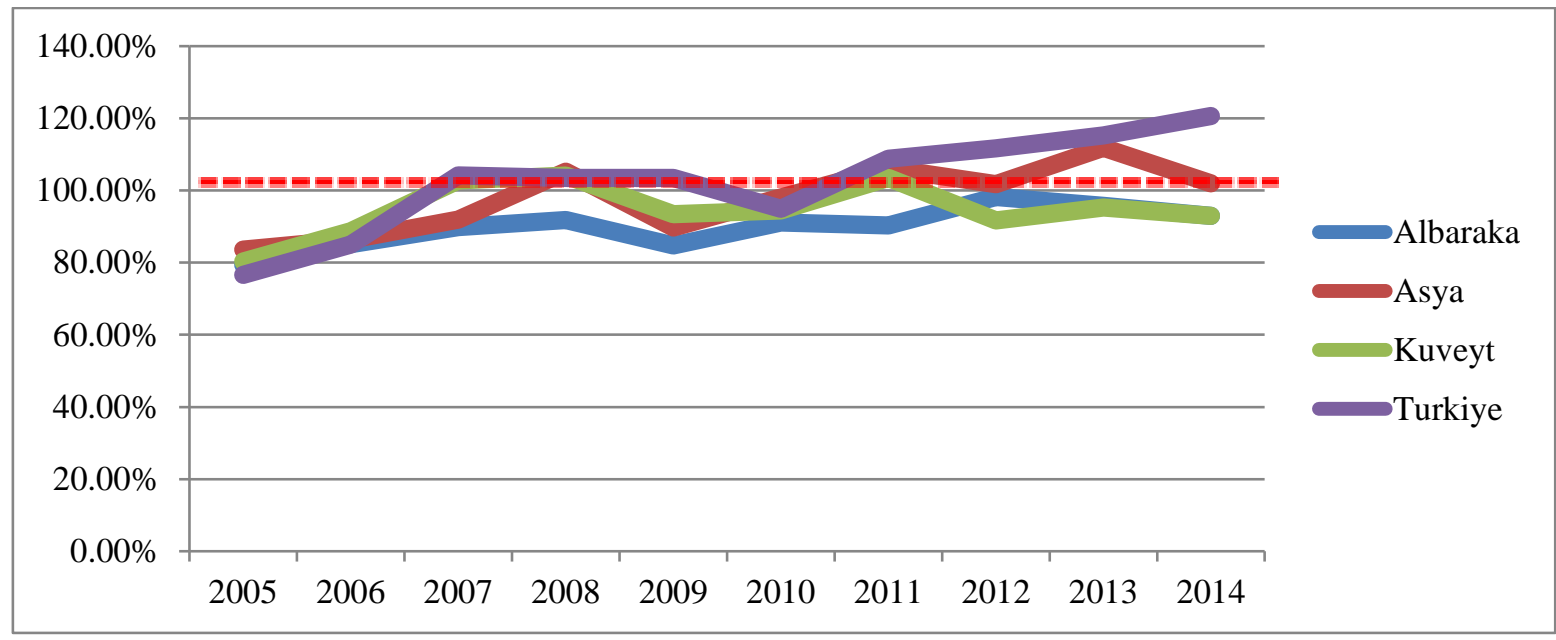

Figure 10. The Loan/Deposit Ratios

In the years between 2011-2013 and in 2008 the index was 100\% (----) that is above the healthy limit, which meant that the Islamic banks were on aggressive business policies, that is the size of the loans exceeded the value of deposits, which has been a liquidity risk.

It may also be an important consideration what the composition of deposits is like, because, if they have a lot of low-value, short-term deposits, instead of the large deposits, the sudden withdraw of the deposits can also cause disturbances in the operation of the banks. Turkiye is classified as 2 due to the value above $100 \%$.

It is clear that the liquidity ratio increased but only slightly whereas the Loan/Deposit ratio was variable, but also slightly.

\subsection{Results of the CAMEL Analysis}

Therefore, for the qualification of the Turkish Islamic banking system we classified various factors, and then the results were averaged. The end result, according to the results of the banking system is 1.83 that is rounded to 2 that is good, which means that basically it is a good banking system, there are just few problems.

\begin{tabular}{|l|c|c|c|c|c|c|}
\hline Banks & C & A & M & E & L & Average \\
\hline Albaraka & 2.00 & 1.00 & 3.00 & 1.00 & 1.00 & 1.60 \\
\hline Asya & 2.00 & 2.50 & 3.50 & 3.00 & 1.00 & 2.40 \\
\hline Kuveyt & 2.00 & 1.00 & 3.00 & 1.00 & 1.00 & 1.60 \\
\hline Turkiye & 2.00 & 1.00 & 3.00 & 1.00 & 1.50 & 1.70 \\
\hline Average & 2.00 & 1.38 & 3.13 & 1.50 & 1.13 & 1.83 \\
\hline
\end{tabular}

Table 1. Results of the Turkish Islamic Banks CAMEL Analysis Source: Based on the Calculation

\section{Summary}

After the 2008 economic crisis, special attention was given to alternative financing techniques, and so to Islamic banks. They are characterized as interest-free banking.

Using the annual reports of the banks in the period between 2005 and 2014 we evaluated the individual banks and the banking system as a whole by indicators, based on of Capital adequacy, Asset quality, the Management efficiency, Profitability, and Liquidity. With the CAMEL analysis, the primary goal was to get a picture of the operation of the Turkish Islamic banks, the developments of their performances in the examined years.

Due to the operational features of the Islamic banks they do not assume high risks, so their operation is not exposed to large losses, at the same time; however, no huge profit is available for them, either. They emphasize partnership, i.e. it is important to consider each transaction from the perspectives of all three participants: the saver, the investor and the bank, too, because whether the transaction brings profit or loss, they are divided among the three participants. This operating principle is important, as it may be relevant for anyone who comes in contact with a bank to monitor their savings because thereby they "can force" banks for safer investments and increase competition between them.

In addition, it is important that thanks to the operating principles we can speak about safer business, because for banks operating on the basis of Islamic religious principles it is forbidden to carry out a number of financing activities violating their religion and these activities can be found in conventional banking, which led to the crisis. These include speculative transactions, or entering transactions with the aforementioned high-risk investments, 
and certain financial market techniques such as securitization are absent. As a result, the "bad" assets did not infect them during the crisis.

On the basis of the calculated indicators we can say that the business of the banks is not endangered. Bank Asya can be considered the weakest among the four banks according to its results. Furthermore, the Turkish Islamic banks performance moved together in most cases. The biggest negative trend appeared in the downward tendency of profitability. The crisis and the changed economic environment were reflected in their performances but did not cause any drastic changes. The strict monetary control of the banks as well as the efforts for safe operation probably contributed to all this. It must be added that there was no bankruptcy in the case of the traditional Turkish banking system, either.

\section{References}

- Balázs J., 2011. Az iszlám bankrendszer: Tanulságok a neoliberális pénzügypolitika figyelmébe, Valóság, Vol. 54. Num. 1.pp. 1-11

- Baka I.-Dancsó J.-Ligeti S.-Szarvas F.-Vágyi F.-Varga J., 2012. Bankismeretek, Budapest, 2012, Tanszék Pénzügyi és Szolgáltató Kft., University book, pp.44-62

- Felcser D.-Körmendi Gy., 2010. Bankválságok nemzetközi tapasztalatai: kezelési eszközök és makrogazdasági következmények

- $\quad$ https://www.mnb.hu/letoltes/felcser-kormendi-mnbszemle-0623.pdf

- Financial statements of Bank Albaraka: http://en.albarakaturk.com.tr/investor_relations/detail.aspx?SectionID=Dr8Cw16dHGqYzoMeqx\%2fjjQ\%3 $\mathrm{d} \% 3 \mathrm{~d} \&$ ContentID=4oEu6KjEmU33gGZTiL4GkQ\%3d\%3d

- http://www.albarakaturk.com.tr/faaliyet-raporlari.aspx

- Financial statements of Bank Asya: http://www.bankasya.com.tr/en/investor-relations-annual-reports.aspx

- $\quad$ Financial statements of Bank Kuveyt: http://www.kuveytturk.com.tr/financial_information.aspxhttp://www.kuveytturk.com.tr/finansal_bilgiler_ha kkimizda.aspx.

- Financial statements of Bank Turkiye: http://www.turkiyefinans.com.tr/en-us/investor-relations/financialdata-and-reports/Pages/annual-reports.aspxhttp://www.turkiyefinans.com.tr/tr-tr/yatirimci-iliskileri/finansalraporlar/Sayfalar/bagimsiz-denetim-raporlari.aspx

- Gálosi M. B., 2010. Iszlám ablak - ablak az iszlámra, Budapesti Corvinus Egyetem, thesis

- MNB: http://www.mnb.hu/penzugyi-stabilitas

- Nagy Gy., 2010. Globális pénzügyi válság - A jelenlegi tényleg más? http://kgk.sze.hu/images/dokumentumok/kautzkiadvany2010/nagy\%20gyula.pdf

- Preiger A. -Mátyás, 2014. Az iszlám jog. Publicationes Universitatis Miskolcinensis Sectio Juridica et Politica, Tomus XXXII., pp. 103-112.: http://www.matarka.hu/koz/ISSN_08666032/tomus_32_2014/ISSN_0866-6032_tomus_32_2014_103-112.pdf

- Reports of Participation Banks Association of Turkey (2009-2013): http://www.tkbb.org.tr/research-andpublications-tkbb-publications-annual-sector-reports

- $\quad$ http://quran.com/30/39

- Varga J., 2011. Az iszlám bankrendszer szerepe a pénzügyi stabilitás helyreállításában, A virtuális intézet Közép-Európa kutatására közleményei 4: (1 (No.7)) pp. 121-132. 